\title{
The influence of tree species on carbon storage in northern China
}

\author{
by Guopeng Chen ${ }^{1}$, Huitao Shen $2,3, *$, Jiansheng $\mathrm{CaO}^{3}$ and Wanjun Zhang ${ }^{3}$
}

\begin{abstract}
Selection of tree species is an important management decision for increasing carbon storage in regional planting programs in China. This study quantifies above and belowground carbon storage by several species in the Desertification Combating Program around Beijing and Tianjin (DCBT). Results show that the total carbon storage of the Pinus davidiana plantation was significantly higher than that of Pinus sylvestris var. mongolica but not significantly differ from plantations of Pinus tabulaeformis and Larix gmelinii var. principis-rupprechtii. Most of the carbon was in the aboveground biomass. These results suggest that tree species have substantial influences on carbon storage, and that species should be considered in improving carbon sequestration potential for afforestation/reforestation projects.
\end{abstract}

Keywords: biomass carbon storage, tree species, afforestation/reforestation

\section{RÉSUMÉ}

Le choix desIl est important de bien choisir les espèces essences d’arbres constitue une importante décision lorsqu'il est question d'd'accroître le stockage de carbone par lavec lentremise des programmes de plantations régionales en Chine. Cette étude quantifie le stockage de carbone au-dessus et dans le sol obtenu pour quelques espèceessences utilisées dans le programme de lutte contre la désertification appliqué autour de Pékin et de Tianjin (Desertification Combating Program around Beijing and Tianjin DCBT). Les résultats indiquent que le stockage total de carbone dans les plantations de Pinus davidiana était significativement plus élevé que dans le cascelles de Pinus sylvestris var. mongolica, mais sans être significativement différent de celui dans les plantations de Pinus tabulaeformis et de Larix gmelinii var. principis-rupprechtii. La majeure partie du carbone se retrouvait dans la biomasse au-dessus du sol. Ces résultats laissent entendre que les espèces essences d'arbres ont une influence significative sur le stockage de carbone et quelles devraient être retenues prises en considération lorsqu'il est question d’améliorer le potentiel de séquestration du carbone des projets de boisement/reboisement.

Mots clés : stockage du carbone dans la biomasse, espèces essence d’arbre, boisement/reboisement

\section{Introduction}

Many proposals for mitigating the effects of global environmental change advocate large-scale plantation for reducing carbon emissions and increasing carbon sequestration (Mao et al. 2011, Chang et al. 2012, Huang et al. 2012). Estimation of carbon sequestration by plantations depends on understanding how they are affected by different management practices, disturbances and by age and composition of stands at a landscape scale (Wang et al. 2009, Liao et al. 2012, He et al. 2013, Li et al. 2013, Wang et al. 2013, Cao et al. 2014). In previous studies, estimates of carbon storage are usually focused on different tree species in homogeneous pedoclimatic conditions (Laungani and Knops 2009, Kanowski and Catterall 2010, Zhang and Wang 2010, Trum et al. 2011). However, uncertainty associated with spatial variability at a regional scale may inhibit accurate carbon storage estimates (Houghton 2005, Sierra et al. 2007, Weishampel et al. 2009). Detailed knowledge about carbon storage by different plantations is limited to assess the carbon balance at a regional scale.

In the late 1990s, the Chinese government initiated six forestry programs (Liu et al. 2010): the Natural Forest Protection Program (NFPP); the Sloping Land Conversion Program
(SLCP); the Desertification Combating Program around Beijing and Tianjin (DCBT); the Shelterbelt Development Program (SBDP); and, the Wildlife Conservation and Nature Reserve Development Program (WCNR). The influence of tree species on carbon storage combined with information on spatial distribution can be used to improve insight in regional carbon budgets (Schulp et al. 2008). Differences in biotic carbon storage between tree species may indicate the effects of future management changes on carbon sequestration. Therefore, knowledge about the effect of tree species on carbon storage may guide species choice in the case of afforestation/ reforestation programs with the objective of enhanced carbon sequestration.

Studies on the influence of species on carbon storage under regional-scale afforestation and reforestation projects in China are lacking. In this study we report on the effects of species on carbon storage in the DCBT program of northern China. With each species, three locations with various climate and edaphic conditions are sampled. From this, average aboveground and belowground carbon per species is calculated. We assumed that average carbon storage at the three locations represents the regional characteristics for each

\footnotetext{
${ }^{1}$ The Institute of forestry Sciences, Bailongjiang Forestry Management Bureau of Gansu Province, 730070 Gansu, China;

${ }^{2}$ The Institute of Geographical Sciences, Hebei Academy of Sciences, 050081 Hebei, China; *corresponding author's email: shenhuitao80@126.com

${ }^{3}$ The Institute of Genetics and Developmental Biology, Chinese Academy of Sciences, 050022 Hebei, China
} 


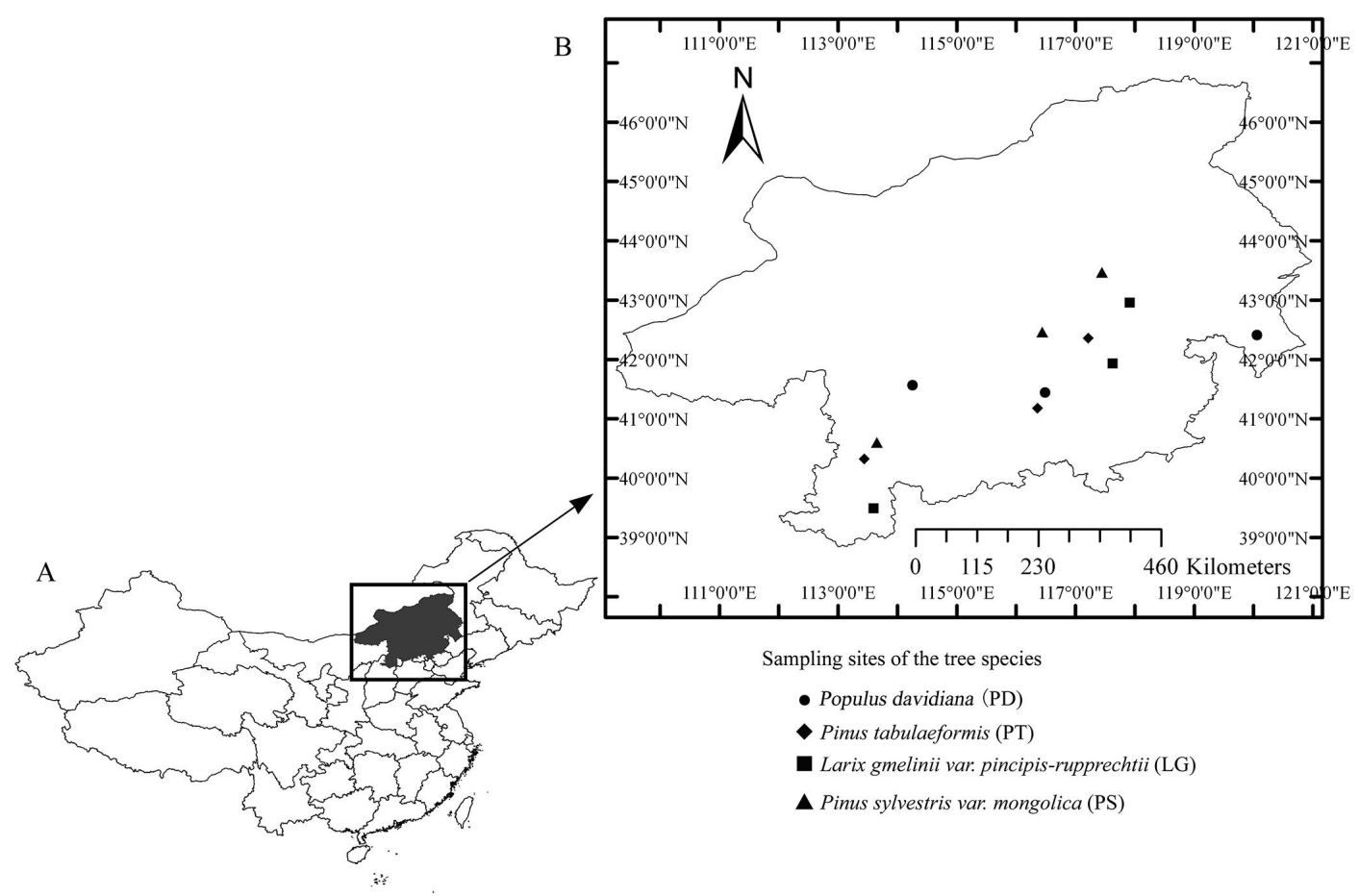

Fig. 1. Area of the Desertification Combating Program around Beijing and Tianjin (DCBT) in China (A) and the sampling sites of four species (B).

Table 1. Characteristics of the four plantations

\begin{tabular}{lcccc}
\hline Variables & Poplar & Chinese pine & Larch & Mongolian pine \\
\hline Density $\left(\right.$ trees ha $\left.{ }^{-1}\right)$ & $1229(278)^{\mathrm{a}}$ & $1933(331)^{\mathrm{a}}$ & $2416(432)^{\mathrm{a}}$ & $1858(318)^{\mathrm{a}}$ \\
Mean tree height $(\mathrm{m})$ & $10.2(2.4)^{\mathrm{b}}$ & $2.1(0.5)^{\mathrm{a}}$ & $4.1(0.7)^{\mathrm{a}}$ & $3.1(0.6)^{\mathrm{a}}$ \\
Mean $\mathrm{DBH}^{\mathrm{a}}(\mathrm{cm})$ & $9.5(1.3)^{\mathrm{b}}$ & $2.5(0.5)^{\mathrm{a}}$ & $5.9(1.1)^{\mathrm{ab}}$ & $4.8(1.6)^{\mathrm{ab}}$ \\
Basal area $\left(\mathrm{m}^{2} \mathrm{ha}^{-1}\right)$ & $8.6(1.2)^{\mathrm{b}}$ & $1.3(0.6)^{\mathrm{a}}$ & $7.7(2.4)^{\mathrm{b}}$ & $3.1(0.7)^{\mathrm{ab}}$
\end{tabular}

${ }^{a} \mathrm{DBH}=$ diameter at breast height $1.3 \mathrm{~m}$. Numbers in parentheses are standard deviations $(n=3)$. The letters a and $\mathrm{b}$ indicate significant differences in the specified ecosystem components based on Tukey tests $(P<0.05)$.

Sampling collection and analysis According to landowners, the three locations (Fig. 1) with 10year-old plantations represent the DCBT region. In AugustSeptember 2011, in each location three $20 \mathrm{~m} \times 20 \mathrm{~m}$ experimental plots were established. Diameter at breast height $(\mathrm{DBH}$, $1.3 \mathrm{~m}$ ) was measured for all trees in each plot. Detailed descriptions of the experimental plantations are summarized in Table 1.

species. The results provide important carbon estimates for this region that may be used as a management baseline for enhancing carbon sequestration.

\section{Material and Methods}

\section{Site description}

The area of the DCBT (Fig. 1) is between $38^{\circ} 50^{\prime} \mathrm{N}, 109^{\circ} 16^{\prime}$ $\mathrm{E}$ and $46^{\circ} 47^{\prime} \mathrm{N}, 120^{\circ} 59^{\prime} \mathrm{E}$ and $400-1800 \mathrm{~m}$ above sea level. The climate is temperate with an average temperature of $12^{\circ} \mathrm{C}$. Annual precipitation ranges from $460 \mathrm{~mm}$ to $595 \mathrm{~mm}$, with $65 \%$ available between June and September (Gao et al. 2008). The planted species under DCBT consists of Populus davidiana Dode, Pinus tabulaeformis Carr., Larix gmelinii var. pincipis-rupprechtii Pilg., Pinus sylvestris var. mongolica Litv. and Betula platyphlla Suk.(Gao et al. 2008). We selected $P$. davidiana (PD), P. tabulaeformis (PT), L. gmelinii (LG), and P. sylvestris (PS) as representing the main plantations under the DCBT program.
Allometric equations between component biomass and independent $(\mathrm{DBH})$ were developed using simple linear regression. The form of allometric equation was $\mathrm{B}=a \mathrm{DBH}^{b}$, where $\mathrm{B}$ is component biomass, $a$ and $b$ are constants. For model generation, nine trees of each species (one tree $\times$ three plots $\times$ three locations) were selected and harvested. Dry weight of the tree components was measured. These allometric equations were used to calculate the biomass of different components for each tree and total biomass for each plot (Table 2). Forest litter was measured by setting up five $1 \mathrm{~m} \times$ $1 \mathrm{~m}$ quadrats located randomly in each plot. All biomass was harvested and dry mass measured. The samples were dried at $65{ }^{\circ} \mathrm{C}$ to constant weight and then ground to $0.25 \mathrm{~mm}$ for chemical analysis (Wang 2006, Wang et al. 2009).

Carbon concentrations of plant components were measured with the potassium dichromate oxidation method (Han et al. 2010). All carbon stored in the aboveground components was used to calculate total aboveground carbon stock; 
Table 2. Allometric equations relating component biomass $(\mathrm{b}, \mathrm{kg}$ ) to $\mathrm{DBH}(\mathrm{cm})$ by species

\begin{tabular}{|c|c|c|c|c|c|c|c|c|c|c|c|c|}
\hline \multirow{2}{*}{$\begin{array}{l}\text { Com- } \\
\text { ponent }\end{array}$} & \multicolumn{3}{|c|}{ Poplar } & \multicolumn{3}{|c|}{ Chinese Pine } & \multicolumn{3}{|c|}{ Larch } & \multicolumn{3}{|c|}{ Mongolian Pine } \\
\hline & $a$ & $b$ & $R^{2}$ & $a$ & $b$ & $R^{2}$ & $a$ & $b$ & $R^{2}$ & $a$ & $b$ & $R^{2}$ \\
\hline Foliage & 0.448 & 0.806 & 0.919 & 0.858 & 0.873 & 0.951 & 0.295 & 1.065 & 0.988 & 1.707 & 0.341 & 0.894 \\
\hline Branch & 0.107 & 1.489 & 0.948 & 0.620 & 1.252 & 0.932 & 0.343 & 1.213 & 0.902 & 0.602 & 0.527 & 0.924 \\
\hline Stem & 0.324 & 1.664 & 0.980 & 0.614 & 0.781 & 0.929 & 0.033 & 2.578 & 0.998 & 0.836 & 0.775 & 0.971 \\
\hline Root & 0.073 & 1.752 & 0.908 & 0.506 & 0.788 & 0.918 & 0.083 & 1.615 & 0.968 & 0.229 & 0.970 & 0.966 \\
\hline
\end{tabular}

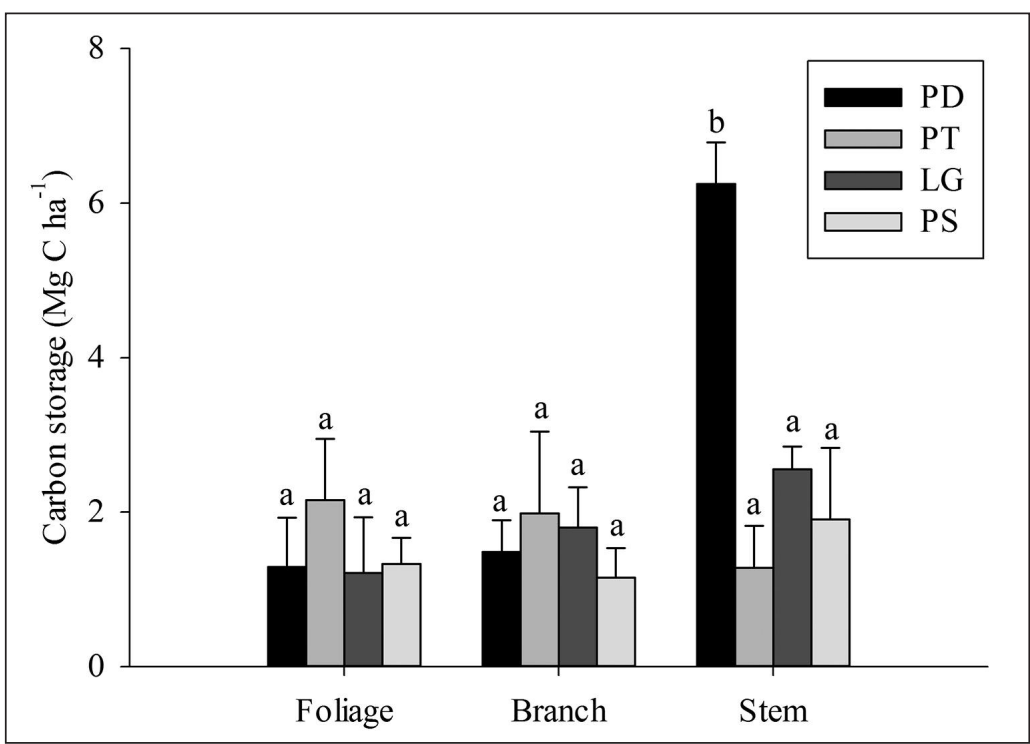

Fig. 2. $C$ storage of aboveground components for the four species. PD, PT, LG and PS represent poplar, Chinese pine, larch and Mongolian pine plantations, respectively. Error bars are standard deviations $(n=3)$. The letters a and b indicate significant differences of the ecosystem components based on Tukey tests $(P<$ 0.05).

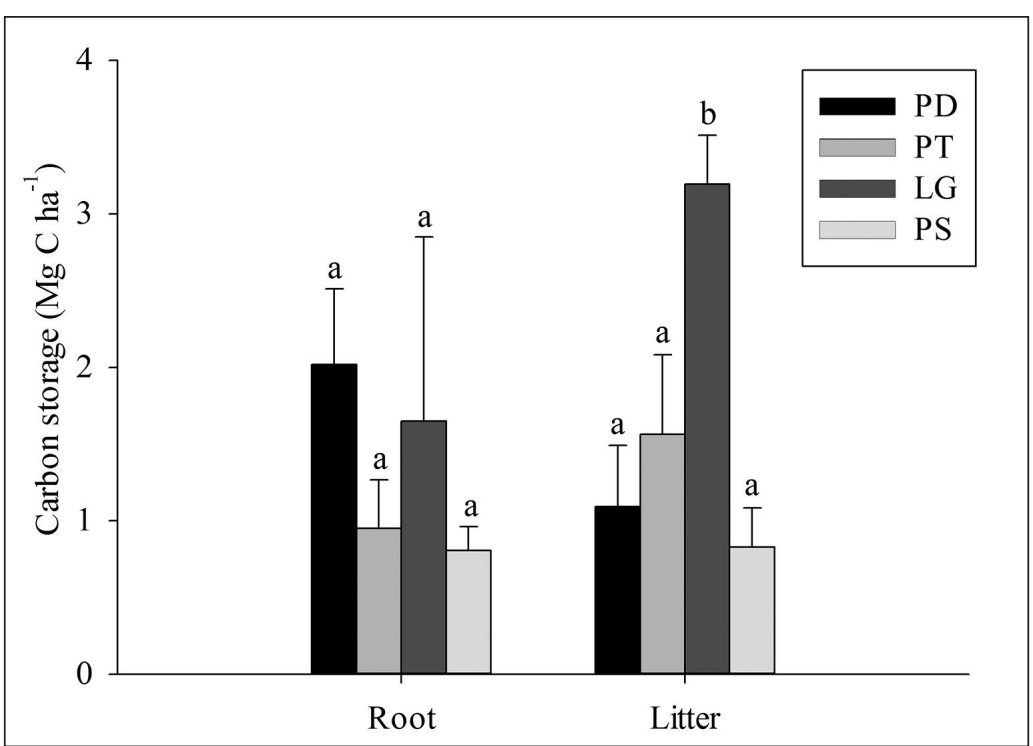

Fig. 3. C storage of belowground compartments for the four species. PD, PT, LG and PS represent the poplar, Chinese pine, larch and Mongolian pine plantations, respectively. Error bars are standard deviations $(n=3)$. The letters a and $\mathrm{b}$ indicate significant differences of the components based on Tukey tests $(P<0.05)$. total root and litter carbon was used to estimate belowground carbon stock (Laganière et al. 2010). Total ecosystem biomass carbon stock was estimated by summing all aboveand belowground storage.

\section{Data analysis}

Variation of aboveground, belowground and total carbon stock was analyzed by one-way analysis of variance. When the outcome was significant, multiple comparisons were made with the Tukey test. Significance levels were set at $P<0.05$ in all statistical analyses. Data analyses were performed using SPSS version 15.0 for Windows (SPSS Inc., Chicago, IL, USA).

\section{Results}

Aboveground carbon storage

Carbon storage by the aboveground components (bole, branches, foliage) varied with species (Fig. 2). Significant differences were observed in the bole carbon storage among the four species $(F=1.41, p=<0.0001)$. There was no significant difference in carbon stocks for foliage and branches (foliage: $F=1.41, p=$ 0.31 ; branch: $F=0.95, p=0.46$ ). Most of the aboveground carbon accumulated in the boles for PD (Populus davidiana), LG (Larix gmelinii) and PS (Pinus sylvestris) plantations, accounting for $69 \%, 46 \%$, and $43 \%$ respectively. However, the boles only accounted for about $24 \%$ of the aboveground carbon stored in the PT (Pinus tabulaeformis) plantation, while branches plus foliage accounted for $76 \%$.

\section{Belowground carbon storage}

Belowground carbon storage includes carbon stored in litter and roots. The carbon storage of roots ranged from 0.8 to $2.0 \mathrm{Mg} \mathrm{ha}^{-1}$ and did not differ significantly among plantations $(F=2.19, p=0.17$; Fig. 3). Total litter carbon storage varied significantly between plantations $(F=22.58, p=<0.0001)$; it was significantly higher in LG (3.2 $\left.\mathrm{Mg} \mathrm{ha}^{-1}\right)$, more than in PD (1.1 Mg ha-1), PT (1.6 $\left.\mathrm{Mg} \mathrm{ha}^{-1}\right)$ and PS (0.8 $\mathrm{Mg} \mathrm{ha}^{-1}$ ) (Fig. 3). 


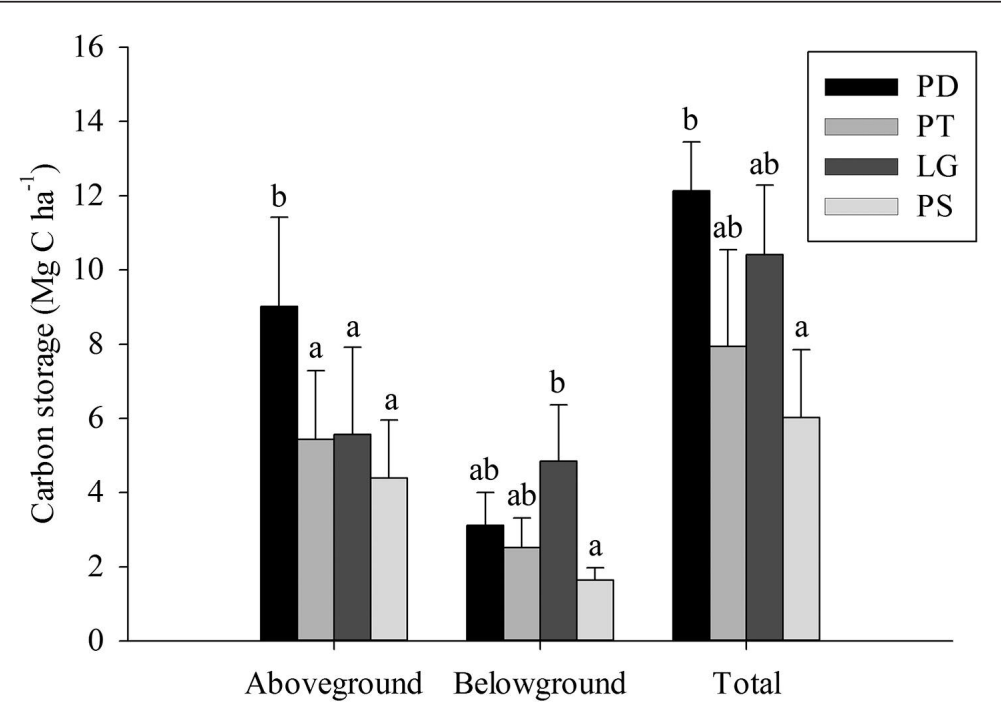

Fig. 4. Aboveground, belowground and total $C$ stocks for the four species of the DCBT program. PD, PT, LG and PS represent poplar, Chinese pine, larch and Mongolian pine plantations, respectively. Error bars are standard deviations $(n=$ 3). The letters $a$ and $b$ indicate significant differences of the specified ecosystem components based on Tukey tests $(P<0.05)$.

\section{Total biomass carbon storage}

Fig. 4 summarizes the results obtained for carbon storage by different plantations. Carbon storage ranged from 6.0 to 12.1 $\mathrm{Mg} \mathrm{C} \mathrm{ha-1}$. PD had significantly higher carbon stock than PS but did not significantly differ from PT and LG. The majority of carbon stock was located aboveground (PD: 74\%; PT: 68\%; LG: $53 \%$; PS: $73 \%$ ), with $26 \%-47 \%$ in belowground carbon (26\%, 32\%, $47 \%$ and $27 \%$ in the PD, PT, LG and PS plantations, respectively).

\section{Discussion}

\section{Aboveground and belowground carbon}

Aboveground and belowground biomass and carbon storage vary on a landscape scale because of spatial heterogeneity in species composition, climate and soil (Somogyi et al. 2007, Mendoza-Ponce and Galicia 2010). In this study, four planted 10-year-old species were selected at different sites as representative of a regional scale. The differences in carbon storage properties are closely linked with the type of species.

Our study has shown that aboveground biomass carbon was significantly higher in the PD plantation than in any of the coniferous plantations (Fig. 4). The difference may result from species selection during afforestation/reforestation (Lal 2005). Our findings provide support that species have effects on aboveground carbon storage (Laungani and Knops 2009, Zhang and Wang, 2010), with lower carbon accumulation in coniferous plantations than in broadleaf plantations. It has been reported that broadleaf species have a rapid growth rate with a high carbon-fixing potential compared with coniferous species (Hu et al. 2008, Wang et al. 2009). The higher carbon stock contribution of the boles in PD may be attributed to the larger aboveground carbon stock compared with other species (Fig. 2).

Jackson et al. (1997) proposed a global average in root carbon stock between 1 and $5 \mathrm{Mg} \mathrm{ha}^{-1}$. In this study, the plantations had a root carbon stock of $0.8-2.0 \mathrm{Mg} \mathrm{ha}^{-1}$, which is comparable. The PD plantation showed higher root carbon stock than the other three coniferous plantations (Fig. 3), which is attributed to the relatively higher growth rate of broadleaf species. Carbon storage in litter in this study ranged from 0.8 to $3.2 \mathrm{Mg} \mathrm{ha}^{-1}$, which is consistent with other litter carbon estimations (Nosetto et al. 2006, Wang et al. 2009, Bisbing et al. 2010, Zhang and Wang 2010). In the present study, carbon stored in litter was higher in the LG and PT plantations than in the PD plantation (Fig. 3), which may be a result from a slower carbon turnover by coniferous species compared with broadleaved species (Trum et al. 2011). However, PD had higher value of litter $\mathrm{C}$ stock than the value of PS, which may reflect differences in the quantity of litter input.

Biomass carbon storage by different plantations Estimating the carbon stored by various species can facilitate decision-making on carbon management ( $\mathrm{He}$ et al. 2013). In this study, the four species, selected at various climate and edaphic conditions to represent the regional condition, were the same age and the plantations had similar densities. Our study shows that the broadleaf species (PD) possesses greater carbon stock than coniferous species, which was consistent with a study by Niu et al. (2009). Our results also show that tree species significantly influence the distribution of carbon above and belowground (Laungani and Knops 2009, Zhang and Wang 2010). For example, the aboveground carbon stock in broadleaf species $\left(9.0 \mathrm{Mg} \mathrm{ha}^{-1}\right)$ was significantly higher than that of the other three coniferous species (Fig. 4). Although we do not have information on species growth rates and therefore cannot recommend species for afforestation/reforestation based on the rate at which a species might be expected to sequester carbon, our data do allow us to identify Populus davidiana as a species which may store a significantly higher carbon stock at the same age after implementation of DCBT in northern China.

The carbon storage of aboveground, belowground, and total ecosystem biomass by different plantations have been derived from some studies in the literature (Table 3). The biomass carbon of the four plantations in this study, which are lower than that of the other studies listed in Table 3, might result from younger plantation age and shorter restoration time (Somogyi et al. 2007, Zheng et al. 2008). This indicates that the younger plantations in DCBT program may represent important reservoirs of future carbon.

\section{Conclusions}

In terms of the DCBT forestry program, our data clearly demonstrates that the PD plantation stored more carbon than the coniferous plantations for the same age and similar tree densities. Aboveground carbon accounted for $53-74 \%$ of total carbon stored by the four species, of which $26-47 \%$ was stored belowground. Additional information on species-specific growth rates, which is currently unavailable for the main tree species, would allow species-level management in afforestation/reforestation projects to be optimized. This study represents the first results of carbon storage by the main 
Table 3. Carbon stocks ( $\mathrm{Mg}$ ha $^{-1}$ ) of aboveground and belowground components and total ecosystem

\begin{tabular}{|c|c|c|c|c|c|c|c|c|c|}
\hline Reference & Study region & Plantations & Species & $\begin{array}{l}\text { MAP a } \\
(\mathrm{mm})\end{array}$ & $\begin{array}{c}\text { MAT }^{\mathbf{b}} \\
\left({ }^{\circ} \mathrm{C}\right)\end{array}$ & $\begin{array}{c}\text { Forest } \\
\text { age }(y \mathbf{y})\end{array}$ & $\begin{array}{l}\text { Above- } \\
\text { ground } \\
\quad \mathrm{C} \\
\left(\mathrm{Mg} \mathrm{ha}^{-1}\right)\end{array}$ & $\begin{array}{l}\text { Below- } \\
\text { ground } \\
\quad \mathrm{C} \\
\left(\mathrm{Mg} \mathrm{ha}^{-1}\right)\end{array}$ & $\begin{array}{c}\text { Total C } \\
\left(\mathrm{Mg} \mathrm{ha}^{-1}\right)\end{array}$ \\
\hline Arevalo et al. 2011 & Alberta, Canada & Hybrid poplar & P. deltoides & 463 & 3 & 9 & 42 & 10.9 & 52.9 \\
\hline Bisbing et al. 2010 & Montana, USA & Western larch & L. occidentalis & 700 & 4.5 & $<20$ & 23.8 & 11.2 & 35 \\
\hline Cao et al. 2012 & Beijing, China & Chinese pine & P. tabulaeformis & 600 & 9 & 25 & 17.6 & 9 & 26.6 \\
\hline \multirow[t]{2}{*}{ Hu et al. 2008} & Inner Mongolia, China & Poplar & P. simonii & 450 & 6.4 & 11 & 20.4 & 5.6 & 26 \\
\hline & & Mongolian pine & P. sylvestris & - & - & 15 & 16.8 & 5.3 & 22.1 \\
\hline Nosetto et al. 2006 & Maitén, Patagonia & Ponderosa pine & P. ponderosa & 424 & 6 & 12 & 12.3 & 17.7 & 30.0 \\
\hline
\end{tabular}

aMAP: Mean annual precipitation

bMAT: Mean annual temperature

species used in the DCBT program. These findings should be of interest for future carbon sequestration evaluations to highlight the most efficient species for improving carbon storage in afforestation/reforestation projects.

\section{Acknowledgements}

This project was supported by grants from the Strategic Priority Research Program of the Chinese Academy of Sciences (Grant No. XDA05060600), the Natural Science Foundation of China (No. 31500448), the Natural Science Foundation of Hebei Province (No. C2015503008) and the Technology Research Program of Hebei Academy of Sciences (16016).

\section{References}

Arevalo C. B. M., J. S. Bhatti, S. X. Chang and D. Sidders. 2011. Land use change effects on ecosystem carbon balance: From agricultural to hybrid poplar plantation. Agr. Ecosyst. Environ. 141(3-4): 342-349.

Bisbing S. M., P. B. Alaback and T. H. DeLuca. 2010. Carbon storage in old-growth and second growth fire-dependent western larch (Larix occidentalis Nutt.) forests of the Inland Northwest, USA. Forest Ecol. Manag. 259(5): 1041-1049.

Cao J., X. Wang, Y. Tian, Z. Wen and T. Zha. 2012. Pattern of carbon allocation across three different stages of stand development of a Chinese pine (Pinus tabulaeformis) forest. Ecol. Res. 27: 883-892. Cao J., Y. Tian, T. S. Zha, X. H. Yang and X. P. Wang. 2014. Carbon allocation dynamic across three different-aged Platycladus orientalis (L.) Franco plantations. Forest Chron. 90 (2):161-168.

Chang R. Y, B. J. Fu, G. H. Liu, S. Wang and X. L. Yao. 2012. The effects of afforestation on soil organic and inorganic carbon: A case study of the Loess Plateau of China. Catena 95: 145-152.

Gao S. Y., C. L. Zhang, X. Y. Zou, Y. Q. Wu, S. Shi and H. D. Li. 2008. Benefits of Beijing-Tianjin Sand source control engineering. China Science Press, Beijing.

Han F., W. Hu, J. Zheng, F. Du and X. Zhang. 2010. Estimating soil organic carbon storage and distribution in a catchment of Loess Plateau, China. Geoderma 154: 261-266.

He Y., L. Qin, Z. Li, X. Liang, M. Shao and L. Tan. 2013. Carbon storage capacity of monoculture and mixed-species plantations in subtropical China. Forest Ecol. Manag. 295: 193-198.

Houghton R.A. 2005. Aboveground Forest Biomass and the Global Carbon Balance. Glob Change Biol. 11: 945-958.

Hu Y. L., D. H. Zeng, Z. P. Fan, G. S. Chen, Q. Zhao and D. Pepper. 2008. Changes in ecosystem carbon stocks following grassland afforestation of semiarid sandy soil in the southeastern Keerqin Sandy Lands, China. J. Arid Environ. 72: 2193-2200.
Huang L., J. Liu, Q. Shao and X. Xu. 2012. Carbon sequestration by forestation across China: Past, present, and future. Renew. Sust. Energ. Rev. 16: 1291-1299.

Jackson R. B., H. A. Mooney and E. D. Schulze. 1997. A global budget for fine root biomass, surface area, and nutrientcontents. PNAS. 94: 7362-7366.

Kanowski J. and C. P. Catterall. 2010. Carbon stocks in aboveground biomass of monoculture plantations, mixed species plantations and environmental restoration plantings in north-east Australia. Ecol. Manage. Restor 11: 119-126.

Laganière J. R. M., D. A. Angers and D. Paré. 2010. Carbon accumulation in agricultural soils after afforestation: A meta-analysis. Global Change Biol. 16: 439-453.

Lal R. 2005. Forest soils and carbon sequestration. Forest Ecol. Manage. 220: 242-258.

Laungani R. and J. M. H. Knops. 2009. The impact of co-occurring tree and grassland species on carbon sequestration and potential biofuel production. Global Change Biol. Bioenerg. 1: 392-403.

Li C. Y., T. S. Zha, J. L. Liu and X. Jia. 2013. Carbon and nitrogen distribution across a chronosequence of secondary lacebark pine in China. Forest. Chron. 89(2): 192-198.

Liao C., Y. Luo, C. Fang, J. Chen and B. Li. 2012. The effects of plantation practice on soil properties based on the comparison between natural and planted forests: A meta-analysis. Glob. Ecol. Biogeogr. 21: 318-327.

Liu C., J. Lu and R. Yin. 2010. An estimation of the effects of China's priority forestry programs on farmers' income. Environ. Manage. 45: 526-540.

Mao R., D. H. Zeng, L. J. Li and Y. L. Hu. 2011. Changes in labile soil organic matter fractions following land use change from monocropping to poplar-based agroforestry systems in a semiarid region of Northeast China. Environ. Monit. Assess. 184: 6845-6853. Mendoza-Ponce A. and L. Galicia. 2010. Aboveground and belowground biomass and carbon pools in highland temperate forest landscape in Central Mexico. Forestry 83: 497-506.

Niu D., S. Wang and Z. Ouyang. 2009. Comparisons of carbon storage in Cunninghamia lanceolata and Michelia macclurei plantations during a 22-year period in southern China. J. Environ. Sci. 21: 801-805.

Nosetto M. D., E. G. Jobbágy and J. M. Paruelo. 2006. Carbon sequestration in semi-arid rangelands: Comparison of Pinus ponderosa plantations and grazing exclusion in NW Patagonia. J. Arid Environ. 67: 142-156.

Schulp C. J. E., G. J. Nabuurs., P. H. Verburg and R. W. de Waal. 2008. Effect of tree species on carbon stocks in forest floor and mineral soil and implications for soil carbon inventories. Forest Ecol. Manage. 256(3): 482-490. 
Sierra C.A. et al. 2007. Total carbon stocks in a tropical forest landscape of the Porce region, Colombia. Forest Ecol. Manage. 243: 299-309.

Somogyi Z., E. Cienciala, R. Mäkipää, P. Muukkonen, A. Lehtonen and P. Weiss. 2007. Indirect methods of large-scale forest biomass estimation. Europ. J. Forest Res. 126: 197-207.

Trum F., H. Titeux, J. Ranger and B. Delvaux. 2011. Influence of tree species on carbon and nitrogen transformation patterns in forest floor profiles. Ann. Forest Sci. 68: 837-847.

Wang C.K. 2006. Biomass allometric equations for 10 co-occurring tree species in Chinese temperate forests. Forest Ecol. Manag. 222: 9-16.

Wang F. M., X. Xu, B. Zou, Z. A. Li and W. X. Zhu. 2013. Biomass accumulation and carbon sequestration in four different aged Casuarina equisetifolia coastal shelterbelt plantations in south China. Plos ONE. doi: 10.1371/journal.pone.0077449.t001.
Wang Q., S. Wang and J. Zhang. 2009. Assessing the effects of vegetation types on carbon storage fifteen years after reforestation on a Chinese fir site. Forest Ecol. Manage. 258: 1437-1441.

Weishampel P., R. Kolka and J. Y. King. 2009. Carbon pools and productivity in a $1-\mathrm{km}^{2}$ heterogeneous forest and peatland mosaic in Minnesota, USA. Forest Ecol. Manage. 257: 747-754.

Zhang Q. and C. Wang. 2010. Carbon density and distribution of six Chinese temperate forests. Sci. China Life Sci. 53: 831-840.

Zheng H., Z. Ouyang, W. Xu, X. Wang, H. Miao, X. Li and Y. Tian. 2008. Variation of carbon storage by different reforestation types in the hilly red soil region of southern China. Forest Ecol. Manag. 255: 1113-1121. 